\title{
Effects of battery chemistry and performance on the life cycle greenhouse gas intensity of electric mobility
}

Hanjiro Ambrose

Transportation, Technology and Policy

Institute of Transportation Studies

University of California, Davis

1605 Tilia St, Davis, CA 95616,

Email: hambrose@ucdavis.edu

Alissa Kendall (Corresponding)

Department of Civil and Environmental Engineering

University of California, Davis,

One Shields Ave, Ghausi Hall, 3143, CA 95616, USA

Email: amkendall@ucdavis.edu

\begin{abstract}
Lithium traction batteries are a key enabling technology for plug-in electric vehicles (PEVs).

Traction battery manufacture contributes to vehicle production emissions, and battery performance can have significant effects on life cycle greenhouse gas (GHG) emissions for PEVs. To assess emissions from PEVs, a life cycle perspective that accounts for vehicle production and operation is needed. However, the contribution of batteries to life cycle emissions hinge on a number of factors that are largely absent from previous analyses, notably the interaction of battery chemistry alternatives and the number of electric vehicle kilometers of travel (e-VKT) delivered by a battery. We compare life cycle GHG emissions from lithiumbased traction batteries for vehicles using a probabilistic approach based on 24 hypothetical vehicles modeled on the current US market. We simulate life-cycle emissions for five commercial lithium chemistries. Examining these chemistries leads to estimates of emissions from battery production of 194-494 $\mathrm{kg} \mathrm{CO}_{2}$ equivalent $\left(\mathrm{CO}_{2} \mathrm{e}\right)$ per kWh of battery capacity. Combined battery production and fuel cycle emissions intensity for plug-in hybrid electric vehicles is 226-386 $\mathrm{g} \mathrm{CO}_{2} \mathrm{e} / \mathrm{e}-\mathrm{VKT}$, and for all-electric vehicles 148-254 $\mathrm{g} \mathrm{CO}_{2} \mathrm{e} / \mathrm{e}-\mathrm{VKT}$. This compares to emissions for vehicle operation alone of 140-244 $\mathrm{g} \mathrm{CO}_{2} \mathrm{e} / \mathrm{e}-\mathrm{VKT}$ for grid-charged electric vehicles. Emissions estimates are highly dependent on the emissions intensity of the operating grid, but other upstream factors including material production emissions, and operating conditions including battery cycle life and climate, also affect life cycle GHG performance. Overall, we find battery production is $5-15 \%$ of vehicle operation GHG emissions on an e-VKT basis.
\end{abstract}

Key Words: Li-ion battery; EV; LCA; carbon footprint 


\section{Introduction}

A transition to plug-in electric vehicles (PEVs), including battery electric vehicles (BEVs) and plug-in hybrid electric vehicles (PHEVs), is promoted as a pathway to reduce greenhouse gas (GHG) emissions from transportation, increase national energy security, and improve local air quality. Lithium-ion batteries (LIBs) have become the preferred choice for energy storage in PEVs because they offer superior energy density, charge cycle performance, and decreased environmental burdens compared to other electrochemical options such as NiMH and lead acid (1). PEVs have been advocated in part because electric powertrain efficiency is significantly greater than conventional internal combustion engines (ICEs), and could lead to deep reductions in operational energy and GHG emissions. As much as $75-95 \%$ of life cycle GHG emissions from ICE vehicles are attributable to fuel consumption and combustion for operation (2-5). However, increased vehicle production emissions, and decreased operation emissions, means that PEVs may experience a greater proportion of life cycle emissions during production compared to ICEs. In fact, on a percent basis, PEVs may have double the emissions from the production phase, and previous studies have shown that battery manufacture alone can be responsible for $35-41 \%$ of those production emissions for a $120-160 \mathrm{~km}$ range PEV ( 24 kWh battery) (6).

Despite the potential importance of battery manufacture and replacement, very few life cycle assessment (LCA) based studies of PEVs or PEV traction batteries have considered multiple battery chemistries and differences in battery degradation and service life. Instead, separate bodies of research have developed with different foci: (i) LCA of PEVs and traction batteries; (ii) studies of electricity grids to determine operating emissions for PEVs; and (iii), empirical study, modeling, and performance testing of vehicle traction batteries. Research progress in these three fields has had limited integration, and which, if implemented, could reveal significant sources of uncertainty in emissions estimates for PEVs and important trade-offs for vehicle and climate policies.

This study builds on these bodies of previous research by offering a novel integration of automotive battery cycle-life modeling and life cycle GHG assessment, with the specific goal of assessing how differences between lithium chemistries will affect GHG emissions performance. We apply a probabilistic modeling approach, Monte Carlo simulation, to capture the inherent variability and uncertainty in predictive modeling of a PEV traction battery life cycle. This provides a new framework for comparison of emissions across life cycle stages and technological designs. In addition to considering five possible LIB chemistries, the assessment captures spatial and temporal heterogeneity in electricity grid emissions, variability in battery-towheels efficiency including ambient climate impacts, causes and effects of battery aging and health, and uncertainty in lifetime e-VKT delivered by a battery.

\section{Materials and Methods}

\subsection{Lithium Ion Traction Batteries}

In short-range configurations, traction battery manufacture is likely a small share of overall PEV production emissions due to the small size of the batteries involved $(<6 \mathrm{kWh})$. Early estimates for plug-in hybrid vehicles suggested that potential production emissions for a 10-15 mile allelectric PHEV to be $2-5 \%$ of the vehicle's life cycle emissions (7). In the United States, ranges 
of PEVs, both pure electric and hybrid, have increased significantly over the last five years as more electric vehicle models have been introduced (see SI: Figure A and Table A for historical data) (23). A favorable policy landscape for vehicles considered "zero emissions" at federal and state levels (24), in addition to rapidly falling battery prices (25), are helping to increase deployment of long-range PEVs. For long-range PEVs, such as an all-electric vehicle with 25 $\mathrm{kWh}$ of on-board storage, battery production likely contributes $12-15 \%$ of overall life cycle emissions $(2 ; \sigma)$.

A variety of lithium cathode and anode materials are being used in, or considered for, mass market vehicles. These chemistries have significantly different expectations for cycle life, from 1000 to over 5000 cycles in vehicle service, as well as different nominal and maximum voltages $(2.4 \mathrm{~V} / 2.8 \mathrm{~V}$ to $3.8 \mathrm{~V} / 4.2 \mathrm{~V})(17)$. These differences affect the choice of battery management systems, cooling systems, and other components (21), and may affect cost. Heterogeneity in material composition of the battery also has implications for both the supply of raw materials and the economic value of recovered and recycled materials (22).

Samaras and Meisterling (2008) was among the earliest studies to examine the life cycle GHG emissions from a PEV, comparing ICE, hybrid electric, and three PHEV applications (30, 60, and $90 \mathrm{~km}$ electric range distances) (7). The study assumed a lithium nickel-cobalt-manganese (NMC) battery chemistry, and modeled the battery's production-related impacts and performance characteristics using the results of an often-cited study, Rydh and Sandén (2005) (8). Rydh and Sandén examined the NMC battery as one of a number of energy storage options for photovoltaic systems (not vehicle applications). At the time of Samaras and Meisterling's research there were no commercially produced PHEV vehicles, so their study was necessarily conjectural. They found relatively small contributions from the battery to the life cycle impacts of the vehicle.

Notter et al. (2010) was among the earliest and most transparent studies that explicitly examined the contribution of LIB production to the life cycle emissions of a BEV (9). They model a lithium manganese-oxide (LMO) battery, developing their own life cycle inventory, and estimate significantly lower production-related impacts compared to those from Rydh and Sandén, and as a consequence those of Samaras and Meisterling. They find the LIB contributes $15 \%$ of life cycle impacts, based on the Ecoindicator 99 approach (10).

Majeau-Bettez et al. (2011) performed an LCA of three PEV battery chemistries, nickel metalhydride (NiMH), lithium nickel-cobalt-manganese (NMC), and lithium iron-phosphate (LFP), and assume that the LFP battery has twice the cycle life, 6000, compared the NCM and NiMH batteries. Like Samaras and Meisterling, they develop the life cycle inventory and battery performance characteristics for the LIB based on the work of Rydh and Sandén. The authors show larger battery manufacturing impacts compared to the earlier studies of Notter et al. and Samaras and Meisterling.

Hawkins et al. (2013) built upon Majeau-Bettez et al.'s results, taking the results of the two lithium-based battery chemistries, NMC and LFP, and contextualizing them in a full vehicle LCA. While Hawkins et al. account for the different masses required for the batteries, the battery use-phase is treated identically and both are assumed to last the vehicle lifetime. Hawkins et al. compared BEVs with ICE gasoline and diesel vehicles and showed the electricity grid used to charge PEV batteries was the most influential determinant of whether BEVs out-performed ICE vehicles. The publication of this article heralded a shift in the modeling approach for PEVs, by 
emphasizing the critical role of the electricity grid and the need for all future studies to consider grid heterogeneity.

Several studies have also found that material production can be a significant contributor to the environmental burden of battery manufacture. Notter et al. (2010) finds copper and aluminum have the largest overall impact on the environmental burden for a LMO battery, even fully allocating the impacts of lithium extraction to lithium salts, and with no credit for recycling of materials (9). Ellingsen et al. (2014), using primary data on NMC battery manufacture, also finds high impacts from graphite, aluminum and copper (31). Dunn et al. (2012) finds much lower impacts for cradle-to-gate battery production, mostly due to significantly lower estimates for cell and pack assembly energies; the authors find that closed loop recycling of key materials (cathode active material, aluminum, and copper) could reduce material production energies by $48 \%(33)$.

A largely separate body of work has considered the effect of including temporal and spatial heterogeneity in electricity grids in the context of marginal rather than average electricity used to charge PEV batteries (the most influential being the work of Graff Zivin et al. 2014 (11)). These studies treat the vehicle rather simply, focusing on new ways of examining the consequences of adding PEV electricity demand to the existing grid. At the same time, additional sources of spatial and temporal heterogeneity that affect battery performance, such as climate effects on batteries have been increasingly studied (12-14). Yuksel and Michalek and Archsmith et al. combine both the spatial heterogeneity of marginal electricity emissions and some climate affects, among other considerations, to provide geography-dependent view of BEV performance $(15 ; 16)$. Both show considerable variability in results by region, but consider only a single battery.

Often absent from EV and LIB life cycle-based studies is research on battery performance testing and cycle life modelling, particularly for lithium cells designed for automotive applications.

Despite the common practice of assuming equal battery lifetimes across chemistries and vehicles in LCA studies, Burke et al. $(2009,2013)$ show 300-500\% variation in the expected cycle life of automotive cells with different cathode materials $(17 ; 18)$. Eddaheck et al. (2015) also finds variation of more than $50 \%$ for battery degradation rates across automotive cells of different lithium chemistries depending on thermal and charge conditions during storage. Mathematical models of battery service life derived from accelerated battery testing also point to the potential for significantly shorter cycle lives than assumed in previous LCA studies, as well as differences across battery chemistries $(19 ; 20)$. The interaction of battery aging and degradation with PEV GHG emissions performance has not been studied, and could present important considerations for original equipment manufacturers (OEMs) and policy stakeholders.

\subsubsection{Lithium Chemistries for Electric Vehicle Batteries}

The conventional structure for a lithium battery consists of a graphite anode and lithium metal oxide cathode, with a lithium salt electrolyte (e.g. LiPF6) in organic solvent (e.g. ethylene carbonate-dimethyl carbonate). Cathode and anode materials are bound to copper and aluminum collector foils with a resin binder and additional solvent. A generalized common reaction process for $\mathrm{C} / \mathrm{LiPF}_{6}$ in $\mathrm{EC}-\mathrm{DMC} / \mathrm{LiMO}_{2}$ consists of:

$$
y C+L i M O 2 \leftrightarrow L i x C y+L i 1-x M O 2, x \sim 0.5, y=6 \text {, voltage } ~ 3.7 V(1)
$$


Reversible exchange of lithium ions between electrodes results in a significant electrical potential, as shown in Equation (1) (34). Some automakers are now employing batteries with lithium metal oxides in both cathode and anode, such as Toshiba's LTO-NMC cells used in the Honda Fit. With some notable exceptions (e.g. Tesla Model S), the majority of automakers have employed pouch or prismatic lithium cells (20-60 Ah), as opposed to cylindrical cells often found in consumer electronics $(<5 \mathrm{Ah})(35)$. While prismatic and pouch cells usually have lower energy density (and specific energy), it is potentially easier to arrange them in modular pack architectures due to their shape. Modules of multiple cell bricks in series can also provide system "balancing," where a differential current is applied to each cell during any charge operation. This limits state of charge (SOC) mismatching, as well as capacity degradation.

To maximize battery lifetimes, SOC is continually balanced across banks of cells by battery management systems (BMS). DOD is limited to $75-85 \%$ of the pack's rated capacity, as batteries have exponentially higher cycle life counts at increasingly low DOD. Utilizing a range of discharge less than the cell's rated capacity improves its lifetime charge capacity and voltage degradation. Traction battery lifetimes are usually expected to exceed standard powertrain warranty periods ( $\sim 60,000$ miles), but manufacturers caution against gradual capacity fade during this time. 5-8 year manufacturer warranties are common for traction batteries; although not all manufacturers guarantee for specific levels of capacity fade during the warranty period, $30 \%$ reduction in capacity is often considered the cut-off point for removal or replacement (SI: Table D). In addition to manufacturer warranties, California's Zero Emissions Vehicle (ZEV) mandate requires that PEV battery warranties must be extended to 10 years to earn $\mathrm{ZEV}$ credits, but this warranty need not specify a level of capacity loss $(36 ; 37)$.

Continued transformational changes in lithium traction batteries are likely due to strong cost drivers and high performance targets in automotive applications (38; 39). Lithium metal couples with lower material costs can reduce battery pack prices, but there are a number of tradeoffs to be made, as evidenced in Table 1 and Figure 1. Cost of material is also a critical decision variable for battery chemistry selection, so cathode materials with high levels of cobalt may not be economic choices for continued large-scale roll out of lithium traction batteries (40). This may explain why no currently mass marketed electric vehicle employs lithium cobalt oxide cells, and the majority of automotive cell suppliers have focused on NCA and LMO configurations $(35 ; 41)$. LFP configurations also have slightly higher costs per $\mathrm{kWh}$ because more cells in series are required due to lower cell voltages (42). LMO-NMC blends seem to provide very low cost, but require more aggressive cooling. LTO-NMC couples operate at lower voltages than other couples currently employed in automotive applications, and their low energy densities may limit their applications despite lower material costs.

\subsubsection{PEV Battery Performance}

Decreased material costs could enable wider-scale roll out of PEVs, but battery life cycle performance should be a key concern due to its influence on production-related emissions. This investment in production emissions will generate life cycle emissions reductions only if batteries endure in vehicular service long enough to realize GHG savings from switching away from gasoline, though GHG savings hinges not only on production emissions from PEVs, but on the GHG-intensity of the electricity used for battery charging. Thus battery service life and battery performance over time should be important considerations in life cycle modeling of PEVs. 
Battery service life is a function of battery degradation, often referred to as battery aging, and is characterized by gradual capacity fade and impedance growth, eventually resulting in the need for battery replacement or vehicle retirement. Both battery cycling and time cause battery aging, and battery aging is accelerated by the DOD and frequency of cycles, thermal conditions, and SOC/voltage conditions experienced by the battery. Three primary underlying chemical processes occur during lithium battery aging: loss of cyclable lithium; electrode material loss to dissolution; and electrolyte degradation (43). While intense charge cycling causes structural degradation of the electrode and active sites, the dominant fade mechanism when stored (i.e. due to time alone) is the growth of a resistive film; both processes also result in a loss of cyclable lithium (44). Capacity degradation has clear impacts on vehicle range, but the combination of resistance-induced power fade and diminished capacity will ultimately determine a battery's service life.

Hot ambient temperature conditions have significant impacts on battery performance degradation during charge cycling and storage, which in turn affects automotive cycle life $(45 ; 46)$. Aging due to cycles or throughput, and aging due to storage at different SOC, can trade dominance depending on operating conditions. For example, increased charge cycling of battery packs can increase estimated battery lifetime compared to calendar or storage-only estimates, if the battery spends longer periods at lower voltages or more optimal temperatures (47), and active thermal management can mitigate aging caused by extreme thermal conditions, but typically increases vehicle energy requirements.

Premature battery degradation is a significant concern for vehicle manufacturers, especially considering the high price of battery replacement; the cost of a $25 \mathrm{kWh}$ LIB pack at current prices is $\$ 7500-12500$ USD (25). Vehicles have experienced premature battery degradation that resulted in the battery realizing less than $60-70 \%$ of the intended cycle life. Idaho National Lab has conducted a long-term road test of four 2012 Nissan Leaf vehicles containing $24 \mathrm{kWh}$ LMO/G battery based on AESC 33Ah cells; after $80467 \mathrm{~km}$ (50000 mi) of daily driving (or approximately 700 cycles), vehicles had experienced over a $25 \%$ reduction in pack capacity (48). Other empirical studies of LMO cells have obtained cycle lives $15-40 \%$ below theoretical estimates when considering automotive operating conditions (19; 49). LFP lifetimes, potentially greater than 3000 cycles at low charge/discharge rates and low ambient temperatures, can decrease by $50 \%$ or more at $40{ }^{\circ} \mathrm{C}$ or with rapid cycling $(20 ; 50)$. Long-cycle life lithium couples, such as Toshiba's LTO cells, have begun to emerge into the market, but currently have little market share. LTO-LMO couples are likely very long lived, with 50Ah prismatic pouches losing less than $1 \%$ capacity over 1000 cycles during fast charge cycling (6C) (18).

\subsection{Methods}

This study uses established life cycle GHG assessment frameworks (51) to analyze life cycle emissions from PEV traction batteries. Non- $\mathrm{CO}_{2} \mathrm{GHG}$ emissions are characterized in equivalent units of carbon dioxide $\left(\mathrm{CO}_{2} \mathrm{e}\right)$ using 100-year Global Warming Potentials (GWPs) from the IPCC's $5^{\text {th }}$ Assessment Report (52). Because there is a great deal of uncertainty in this research, the analysis uses a probabilistic rather than deterministic approach, which is increasingly a requirement of life cycle assessment guidance and standards (53). Probabilistic or stochastic models allow for estimation of parameter values, such as emissions or energy consumption, when individual parameters are not precisely known, a common challenge in life cycle assessment. Fuzzy set theory is frequently used to estimate unknown parameter values and Monte Carlo simulation is well accepted as an uncertainty propagation method in quantitative 
decision analysis $(54 ; 55)$, and both are used in this study to carry out probabilistic life cycle modeling.

Monte Carlo requires probability density functions (PDFs) for expected parameter distributions, which are then used in the context of repeated sampling to estimate results as confidence intervals, rather than point estimates. Probabilistic modeling is also used in this study iteratively to identify key parameters and interrogate underlying assumptions. Comparison of the impacts of parameter uncertainty (caused by a lack of available knowledge/data) and variability (fluctuations inherent to the system) on model outputs is also explored (56).

\section{Calculations}

\subsection{Scope of analysis}

The scope of the life cycle GHG assessment reflects the goal of this study; to estimate the influence of battery service life and battery performance on life cycle GHG emissions. The life cycle stages included in the analysis are: battery material processing, battery manufacturing, and the battery use-phase (including electricity used during charging). The material processing phase encompasses all the production steps prior to assembly for the cell (cathode active material, anode active material, binders, and electrolyte), packaging (plastics, insulation, etc.), and battery management systems (BMSs). Battery material inventories are grouped into four component types: electrodes (cathode/anode active materials, terminals and collector foils), structural (packaging, buss-bars, etc.), electrolyte, and management systems (including BMS and thermal).

We consider five lithium chemistries (cathode-anode couples): NCA-G, NMC-G, LMO-G, LFP$\mathrm{G}$, and LMO-LTO (as described in Table 1), and estimate the composition and material requirements for seven traction battery design scenarios based on intended range, motor power, glider body energy requirements, cell structure, and thermal management of current on-road vehicles, as described in Table 2 . An iterative calculator for battery mass and volume, charge characteristics, and materials is employed based on the BatPaC model $(21 ; 26)$. The model allows for comparison between the material and energy flows for different chemistries based on a set of design scenarios centered on vehicle end-use, power requirements, and thermal considerations. Traction battery design scenarios are constructed to be representative of the PEV market, as well as capture significant differences in battery production and composition across vehicle design (PHEV or BEV) and intended range.

Energy requirements and GHG emissions for these traction battery design scenarios are then used to develop sampling distributions for 24 PEV models representing the current US PEV market. The unit of reporting in this analysis reflects the primary function of the battery; energy storage to provide e-VKT. Thus results of the battery life cycle GHG analysis are normalized by the lifetime e-VKT. This normalized metric is appropriate for comparing the utilization potential of batteries $(32 ; 57)$. Vehicle e-VKT is simulated across vehicle and chemistry combinations based on the expected cycle lives of each battery chemistry.

\subsection{Battery System Design and Production Emissions}

Battery design is considered through seven scenarios constructed around common PEV vehicle classes (PHEV15, PHEV40, PHEV80, BEV80, BEV200, BEV250). Battery scenarios are modeled based on intended vehicle type (PHEV or BEV), intended vehicle electric range, battery pack configuration, electric motor power, and the thermal management system. Data for material composition per $\mathrm{kWh}$, emissions per $\mathrm{kWh}$, energy requirements per $\mathrm{kWh}$, as well as 
pack energy density and mass were developed and used to generate sampling distributions. These distributions were then applied to several vehicle designs within the PEV vehicle class.

While battery packs are usually designed for a specific vehicle, real-world performance of a particular battery system will vary based on different vehicle types. To assess variation in vehicle performance within battery design scenarios, we look at several specific vehicle models for each PEV class; for instance, the Ford C-max and Fusion Energi, as well as the Honda Accord Plug-in, are all simulated from the same underlying distribution of material composition and energy requirements, but adjusted for the specific vehicle design by the kWh capacity.

All batteries are simulated as a prismatic cell type and a blend of steel and aluminum structural elements, and with only one exception, all scenarios utilize active liquid cooling systems. Battery cycle life is used to simulate energy throughput and calculate lifetime e-VKT. Lifetime e-VKT for each simulated vehicle and chemistry combination is based on initial estimated allelectric vehicle range, expected gradual capacity fade during vehicle service life, and estimated cycle life by chemistry. Gradual capacity fade is estimated for small charge cycle intervals ( $<100$ cycles), and the full electric range delivered by the charge cycle is used to estimate eVKT. The distributions of key parameters are detailed in Table 3.

End of LIB vehicular service life is assumed to occur after a 30\% reduction in rated energy storage capacity from when the battery was new. Battery cycle life is estimated for each lithium couple based on a meta-analysis of published sources and other publically available data. Table B in the Supplementary Information (SI) summarizes the key parameters from the studies included in the meta-analysis. Empirical test data of prismatic or pouch cells are used when available; the most likely cycle life outcome is assumed to occur at or near ambient temperatures with relatively low $(\sim 2 \mathrm{C})$ charge/discharge rates $(58)$. Lower-bound cycle life is assumed to occur due to calendar aging or cycling at elevated temperatures, as opposed to increased high crate cycling. Aging effects and cycling effects are considered to be additive (59), and differences between vehicle duty cycles are simulated by way of thermal impacts (e.g. increased accessory load and increased battery degradation). Upper-bound cycle life is estimated for optimal DOD cycling patterns and calendar storage limits, indicating the maximum expected cycles to be delivered by the battery before capacity fade thresholds are reached. Extrapolated estimates are used where no complete cycle life data is available.

Material production emissions estimates were calculated from life cycle material inventories in the 2014 Greenhouse Gases, Regulated Emissions, and Energy Use in Transportation Model (GREET) (60). The material life cycle inventories (LCIs) are consistent across chemistries. A distribution of emissions factors for electricity consumed during cell and pack assembly and vehicle use-phase is estimated from regional US emissions factors (16) (SI: Figure B).

Energy consumed directly in cell and pack assembly is simulated stochastically based on existing inventories in published studies. Energy requirements for cell and pack assembly are assumed to be the same across battery chemistries. Fuel-cycle energy consumption is based on vehicle specific energy requirements $(\mathrm{Wh} / \mathrm{km})$, charger efficiency, and accessory load. Charger efficiency varies based on the system and charging rate, but is typically between $85-95 \%$. Climate impacts on accessory load factor are estimated to increase per mile energy consumption by $0-15 \%(15)$.

Production of the BMS is modeled based on results from Dunn et al. (2012) for a $5 \mathrm{kWh}$ $\mathrm{LiFePO}_{4}$ battery. Data from general electronics manufacture is used where specific data for 
process burdens of circuit boards and semiconductors in BMS systems was unavailable. Recycling is not considered in this data (meaning no recycling credit is assigned to the BMS), however materials preserved in the manufacturing process (such as binders), are considered in the inventory.

\subsection{Electricity Grid Emissions}

GHG emissions from electricity consumption are influential in determining the GHG intensity of battery operation, but also affect manufacturing because some processes are electricity-intensive such as cell and pack assembly. Understandably, much of the detailed modeling of use-phase impacts for PEVs has focused on variability in generation source, such as regional or temporal variations in electrical grids (61), and whether PEV charging demand should be modeled as marginal demand (e.g. as an additional unit of demand on the grid), or should be considered part of existing demand (11).

Future electric vehicle charging at high penetration rates would represent significant demand for electricity, which could have modest to severe impacts on local utility grid emissions factors based on penetration of renewables, energy storage systems, electric vehicle range, level of public charging deployment, charging schedules, and charging rates (62-66). Current and future changes to the electricity generation system in the US will undoubtedly affect PEV emissions performance, and disparate carbon and climate policies at the state level are potentially exacerbating variation across regional emissions factors $(67 ; 68)$. Though these issues are important, this analysis does not include a prediction of future electricity grid emissions, but rather looks to recent history to estimate emissions from U.S. electricity and treats PEV charging as marginal demand.

There appears to be a trend towards representing PEV charging demand as marginal, a paradigm shift initiated by the work of Graff-Zivin et al. and the successive studies that have built upon it (11). In accordance with this trend we use the results of Archsmith et al., which report estimates of life cycle GHG emissions for marginal demand across the North American Electric Reliability Corporation regions in the lower 48 states (69). We chose this study because, unlike other available marginal emissions estimates, it includes total fuel cycle GHG emissions (rather than combustion-only emissions from power plants) and includes the contribution of marginal electricity supply generated from renewables.

\subsection{Summary of Parameter distributions}

To implement a probability based life cycle model, parameter values must be represented as PDFs rather than point estimates. Table 3 summarizes the parameter PDFs developed and used in this analysis.

\subsection{Limitations}

This study does not consider potential interactions of vehicle design, range, and battery chemistry on cycle life; it is possible that cycle life for certain chemistries is longer in particular vehicle designs due to correlation between vehicle type and frequency of certain drive cycles. The effects of different thermal management strategies on average pack temperatures and impacts on battery aging are also not considered. Regional levels of PEV deployment could also impact the probability of the occurrence of specific climate impacts or emissions from electricity. Changes in future production systems, raw material provision, or operating grid efficiency could have significant impacts on emissions estimates and are not addressed in this study. 
Despite the widespread use of probabilistic modeling approaches in quantitative analysis, they suffer from several criticisms. Inappropriate or arbitrary parameter distributions gives false confidence in unreliable results, lack of uncertainty incorporated into scenario analysis yields little information on key factors, and independent sampling of correlated parameters reduces comparability between modeled product stages or systems. Dependent sampling has been used to facilitate comparisons between product stages (70); to that end, the same distribution of electricity emissions factors is used for production and use-phase energy consumption. Fuzzy set quantitative analysis is used in this study to derive parameter distributions from empirical data, with the goal of limiting arbitrary application of density functions to parameters (71).

\section{Results}

While battery composition varies considerably across chemistries (Figure 2a), GHG emissions impacts are predominately due to a few materials. Including the battery management system (BMS), GHG emissions from material production were on average $20 \%$ of total battery production emissions (Figure $2 \mathrm{~b}$ ). Aluminum was responsible for approximately $40 \%$ of material production GWP for all five chemistries. Emissions attributable to energy directly consumed in cell and pack assembly was $\sim 80 \%$ of total production emissions, or $157-475 \mathrm{~kg}$ $\mathrm{CO}_{2} \mathrm{e} / \mathrm{kWh}$.

As shown in Figure 3, mean cradle-to-gate GWP intensity for LIB chemistries is 256-261 $\mathrm{kg} / \mathrm{kWh}$, with only LFP and LTO showing statistically significant differences in production GWP between chemistries (Tukey-Kramer, $\alpha=0.05$ ). Production emissions are log normally distributed, ranging widely from 194-494 kg/kWh; upper bound estimates were predictably correlated with more carbon intensive electricity for cell assembly.

Significant differences are also observed across vehicle configurations and vehicle electric range (Figure 4). Battery production emissions intensity (e.g. per kWh of capacity) is $4 \%$ higher for PHEVs on average compared to BEV batteries. Small batteries ( $\sim 5 \mathrm{kWh})$ had higher production emissions per $\mathrm{kWh}$ of capacity because many battery components or systems did not scale completely with pack size. Estimated lifetime e-VKT for traction batteries was 26000-86000 eVKT, with significantly shorter estimates for PHEVs compared to BEVs. Lifetime e-VKT for BEV vehicles was $\sim 95,000$ kilometers across all chemistries; long range vehicles, such as the Tesla model S, could reach well in excess of 241,000 kilometers considering charge cycle degradation only. PHEV lifetime was 13000-53000 e-VKT across chemistries and vehicles.

Considering a likely electricity emissions factor range of $660-970 \mathrm{~g} \mathrm{CO}_{2} \mathrm{e} / \mathrm{kWh}$, fuel cycle emissions rates for the US were estimated at 140-244 $\mathrm{g} \mathrm{CO}_{2} \mathrm{e} / \mathrm{e}-\mathrm{VKT}$. The range of this estimate is likely more reflective of regional variability than temporal or seasonal variability within regions. However, if the climate effects on batteries and grid emissions intensity were varied in a geospatially explicit manner, this would likely change (see Archsmith et al. for a discussion of this) (16). Battery production emissions of $4-17 \mathrm{~g} \mathrm{CO}_{2} \mathrm{e} / \mathrm{e}-\mathrm{VKT}$ were $\sim 7 \%$ on average of comparable fuel cycle emissions (Figure 5). The combined emissions rate (production and fuel cycle) was 148-261 $\mathrm{g} \mathrm{CO}_{2} \mathrm{e} / \mathrm{e}-\mathrm{VKT}$.

Uncertainty in total life cycle emissions rates was predominately driven by emissions from the operating grid (Figure 6). Climate and cycle-life were also key factors for overall emissions rates. Larger uncertainties in the life-time of NCA batteries, combined with slightly higher material production emissions estimates, led to stronger affects from NCA lifetime estimates. Climate and charging efficiency assumptions also varied total emissions estimates by $\pm 5 \%$. 


\section{Discussion}

Lithium ion cell manufacture can be highly energy intensive. For example, high temperatures and sterile conditions, which are energy-intensive and thus emissions-intensive processes, are required for binding cathode and anode active materials to collector foils, trimming and filling pouches with electrolyte, as well as sealing and testing of cells (26). Recent studies have illustrated that estimates of energy consumption during cell manufacture can drive estimates of overall battery production emissions $(27 ; 28)$ Estimates for cradle to gate emissions for early Japanese cells were approximately $70 \mathrm{~kg} \mathrm{CO} 2 \mathrm{e} / \mathrm{kWh}(29)$, with direct energy in cell manufacture of 0-28.3 MJ/kWh (30). More recent studies have found much higher impacts: $133-338 \mathrm{~kg}$ $\mathrm{CO}_{2} \mathrm{e} / \mathrm{kWh}$ based on energy consumption of $326-2318 \mathrm{MJ} / \mathrm{kWh}$ for cell manufacture $(28 ; 31$; 32). While earlier estimates are based primarily on laboratory test data, both Bauer et al. (2010) and Ellingsen et al. (2014), with the highest published estimates for cell manufacture energies, rely on inventories and other primary data from of existing cell manufacturers.

Previous studies report a wide range of estimates for traction battery life cycle GHG emissions: 38-487 $\mathrm{kg} \mathrm{CO}_{2} \mathrm{e} / \mathrm{kWh}$. This study's estimates fall within that range, 193-494 $\mathrm{kg} \mathrm{CO}_{2} \mathrm{e} / \mathrm{kWh}$ (Figure 7). Despite very different findings for emissions per $\mathrm{kWh}$ of capacity, Notter et al. (2010) and Zackrisson et al. (2012) find similar production impacts of 6-8 $\mathrm{g} \mathrm{CO}_{2} \mathrm{e} / \mathrm{km}$, with fuel cycle impacts of 62-109 $\mathrm{g} \mathrm{CO}_{2} \mathrm{e} / \mathrm{km}$. Both Notter et al. (2010) and Dunn et al. (2012) stand out with very low estimates for battery production in comparison to other studies. While previous research also point towards high-energy requirements (and emissions potential) from cell assembly, the significance of battery production emissions on a per VKT basis is strongly affected by battery cycle life. This is due to the large uncertainties in current lithium battery performance, as well as the wide variability in cycle life expectations across chemistries.

Early estimates for battery production of approximately $70 \mathrm{~kg} \mathrm{CO}_{2} \mathrm{e} / \mathrm{kWh}$ or less suggested GHG emissions reduction potential from electric vehicles after only 200 cycles (compared to a comparable conventional gasoline ICE vehicle), when charged from a typical electricity grid dominated by fossil fuels coal and natural gas (72). Comparing to a conventional vehicle producing $220 \mathrm{~g} \mathrm{CO}_{2} \mathrm{e} / \mathrm{VKT}$, GHG payback periods for battery production (2-8 metric tons $\mathrm{CO}_{2} \mathrm{e}$ on average), are approximately 400-1150 cycles. This estimate, while not taking into account battery aging, is already close to or exceeding battery cycle life for LMO configurations. A push towards longer-range vehicles and larger capacity batteries could exacerbate uncertainties about life cycle performance by further extending carbon payback periods. This underscores the need for life cycle GHG accounting; estimates of emissions performance based solely on the fuel cycle or tail pipe emissions could miss structural shifts in emissions between production and usephase.

Dependent sampling is used in this study to emphasize comparability within the life cycle GHG assessment framework and reveal non-intuitive trade PEV LIB Batteries offs between use-phase and production emissions. Some additional scenarios highlight this point. Consider the case where battery production and vehicle operation occur with different underlying distributions for electricity emissions factors. This is a reasonable scenario to consider as the majority of automotive battery cells, including those used in the US, are currently manufactured in China and other Asian countries (SI: Table C). In addition, over $50 \%$ of the US PEV market is in a 
single state: California. The state's reported utility emissions factors are also much lower than national averages. Using a production grid intensity closer to some Asian manufacturing hubs (around $1 \mathrm{~kg} \mathrm{CO} 2 \mathrm{e} / \mathrm{kWh}$ ), and an average operating grid intensity for California (approximately $0.23 \mathrm{kgCO}_{2} \mathrm{e} / \mathrm{kWh}$ ), production emissions increase to $214-687 \mathrm{~kg} / \mathrm{kWh}$, but the life cycle emissions rate decreases to $94-135 \mathrm{~g} \mathrm{CO}_{2} \mathrm{e} / \mathrm{e}-\mathrm{VKT}$. Doubling the expected range of production energy emissions intensities has little to modest impacts on per kilometer emissions rates, as exhibited by these results. Cycle life (including climate impacts), and operating grid emissions intensity are likely the key factors affecting traction battery emissions performance.

Effective throughput of the traction battery over expected cycles has been used to estimate the total kilometers travelled by the vehicle. Lifetime e-VKT generation for long-range traction batteries is currently highly uncertain due to a number of factors; some, including driver behavior, mechanical failure, and vehicle accidents, are not assessed in this study. Regional variations in travel patterns and travel demands could also impact lifetime e-VKT. Further research is required to assess how these factors will impact traction battery carbon payback period. High mileage vehicles may come up against calendar aging considerations or accident/mechanical failure before maximum mileages are reached. As more data on PEV usage and real-world battery cycle performance becomes available, estimates of effective lifetime eVKT for PEVs is also likely to improve.

\section{Conclusions}

This research highlights a number of factors that influence the performance of PEVs from a GHG emissions standpoint; these findings can be used to inform the regulatory landscape for deployment of PEVs in the U.S. and globally, as well as shape engineering decisions for vehicle OEMs. This probabilistic approach to considering life cycle battery performance as a function of chemistry and based on a meta-analysis of battery performance data, shows that the exclusion of production-related emissions for PEVs and realistic operating performance may ignore tradeoffs in production and operation emissions of PEVs. This means a life cycle approach for regulating emissions intensity $\left(\mathrm{g} \mathrm{CO}_{2} \mathrm{e} / \mathrm{VKT}\right)$ may be required to ensure that policies intended to reduce GHG emissions and preferentially encourage low emissions vehicles are successful. This conclusion supports the findings of previous work on other production-related emissions, even for non PEVs, such as those from lightweight materials, which can overwhelm the emissions reduction achieved during vehicle operation (73). Projections of future grid $\mathrm{CO}_{2} \mathrm{e}$ emissions intensity, which suggest significant reductions over time, and increasingly efficient ICE vehicle operation, serve to increase the contribution of production emissions to life cycle emissions for light-duty vehicles, and suggest that the need for a life cycle perspective in regulatory frameworks.

\section{Acknowledgements}

This research was supported in part by the National Science Foundation Award Number CBET1337095, and the National Center for Sustainable Transportation research grant entitled Program for vehicle regulatory reform: Assessing life cycle-based greenhouse gas standards.

\section{References Cited}


[1] Ambrose, H., D. Gershenson, A. Gershenson, and D. Kammen. Driving rural energy access: a secondlife application for electric-vehicle batteries. Environmental Research Letters, Vol. 9, No. 9, 2014, p. 094004.

[2] Bauer, C., J. Hofer, H.-J. Althaus, A. Del Duce, and A. Simons. The environmental performance of current and future passenger vehicles: Life Cycle Assessment based on a novel scenario analysis framework. Applied Energy, In Press.

[3] Castro, M. B., J. A. Remmerswaal, and M. A. Reuter. Life cycle impact assessment of the average passenger vehicle in the Netherlands. The International Journal of Life Cycle Assessment, Vol. 8, No. 5, 2003, pp. 297-304.

[4] Geyer, R. Parametric assessment of climate change impacts of automotive material substitution. Environmental science \& technology, Vol. 42, No. 18, 2008, pp. 6973-6979.

[5] Kim, H. C., G. A. Keoleian, D. E. Grande, and J. C. Bean. Life cycle optimization of automobile replacement: model and application. Environmental science \& technology, Vol. 37, No. 23, 2003, pp. 5407-5413.

[6] Hawkins, T. R., B. Singh, G. Majeau-Bettez, and A. H. Strømman. Comparative environmental life cycle assessment of conventional and electric vehicles. Journal of Industrial Ecology, Vol. 17, No. 1, 2013, pp. 53-64.

[7] Samaras, C., and K. Meisterling. Life Cycle Assessment of Greenhouse Gas Emissions from Plug-in Hybrid Vehicles: Implications for Policy. Environmental science \& technology, Vol. 42, No. 9, 2008, pp. 3170-3176.

[8] Rydh, C. J., and B. A. Sandén. Energy analysis of batteries in photovoltaic systems. Part I:

Performance and energy requirements. Energy Conversion and Management, Vol. 46, No. 11-12, 2005, pp. 1957-1979.

[9] Notter, D. A., M. Gauch, R. Widmer, P. Wager, A. Stamp, R. Zah, and H.-J. r. Althaus. Contribution of Li-ion batteries to the environmental impact of electric vehicles. Environmental science \& technology, Vol. 44, No. 17, 2010, pp. 6550-6556.

[10] Hawkins, T. R., O. M. Gausen, and A. H. Strømman. Environmental impacts of hybrid and electric vehicles-a review. The International Journal of Life Cycle Assessment, Vol. 17, No. 8, 2012, pp. $997-$ 1014.

[11] Graff Zivin, J. S., M. J. Kotchen, and E. T. Mansur. Spatial and temporal heterogeneity of marginal emissions: implications for electric cars and other electricity-shifting policies. Journal of Economic Behavior \& Organization, 2014.

[12] Meyer, N., I. Whittal, and M. C. Loiselle-Lapointe. The Impact of Driving Cycle and Climate on Electrical Consumption \& Range of Fully Electric Passenger Vehicles. Presented at EVS26 International Battery, Hybrid and Fuel Cell Electric Vehicle Symposium, Los Angeles, CA, 2012.

[13] Kambly, K. R., and T. H. Bradley. Estimating the HVAC energy consumption of plug-in electric vehicles. Journal of Power Sources, Vol. 259, 2014, pp. 117-124.

[14] Kambly, K., and T. H. Bradley. Geographical and temporal differences in electric vehicle range due to cabin conditioning energy consumption. Journal of Power Sources, Vol. 275, 2015, pp. 468-475.

[15] Yuksel, T., and J. J. Michalek. Effects of Regional Temperature on Electric Vehicle Efficiency, Range, and Emissions in the United States. Environmental science \& technology, Vol. 49, No. 6, 2015, pp. 3974-3980. 
[16] Archsmith, J., A. Kendall, and D. Rapson. From Cradle to Junkyard: Assessing the life cycle Greenhouse Gas Benefits of Electric Vehicles. Transportation Economics, Vol. Accepted, 2015.

[17] Burke, A., and M. Miller. Performance characteristics of lithium-ion batteries of various chemistries for plug-in hybrid vehicles. Presented at EVS24 International Battery, Hybrid and Fuel Cell Electric Vehicle Symposium, 2009.

[18] Burke, A. Fast Charging (up to 6C) of Lithium-Ion Cells and Modules: Electrical and Thermal Response and Life Cycle Tests. Lithium-Ion Batteries: Advances and Applications, 2013, p. 41.

[19] Gu, W., Z. Sun, X. Wei, and H. Dai. A new method of accelerated life testing based on the Grey System Theory for a model-based lithium-ion battery life evaluation system. Journal of Power Sources, Vol. 267, 2014, pp. 366-379.

[20] Omar, N., M. A. Monem, Y. Firouz, J. Salminen, J. Smekens, O. Hegazy, H. Gaulous, G. Mulder, P. Van den Bossche, and T. Coosemans. Lithium iron phosphate based battery-Assessment of the aging parameters and development of cycle life model. Applied Energy, Vol. 113, 2014, pp. 1575-1585.

[21] Nelson, P., K. Bloom, and D. I Dees. Modeling the performance and cost of lithium-ion batteries for electric-drive vehicles.In, Argonne National Laboratory (ANL), Argonne, IL (United States), 2011.

[22] Wang, X., G. Gaustad, C. W. Babbitt, and K. Richa. Economies of scale for future lithium-ion battery recycling infrastructure. Resources, Conservation and Recycling, Vol. 83, 2014, pp. 53-62.

[23] U.S. Department of Energy. Alternative Fuels Data Center - Vehicle Sales. http://www.afdc.energy.gov/. Accessed 7/1/2015.

[24] Mock, P., and Z. Yang. Driving electrification: A global comparison of fiscal incentive policy for electric vehicles. The International Council on Clean Transportation (ICCT). URL http://www. theicct. org/sites/default/files/publications/ICCT_EV-fiscal-incentives_20140506. pdf. Last accessed, Vol. 22, No. 6, 2014, p. 2014.

[25] Nykvist, B., and M. Nilsson. Rapidly falling costs of battery packs for electric vehicles. Nature Climate Change, 2015.

[26] Dunn, J., L. Gaines, M. Barnes, M. Wang, and J. Sullivan. Material and energy flows in the materials production, assembly, and end-of-life stages of the automotive lithium-ion battery life cycle.In, Argonne National Laboratory (ANL), 2012.

[27] Zackrisson, M., L. Avellán, and J. Orlenius. Life cycle assessment of lithium-ion batteries for plug-in hybrid electric vehicles - Critical issues. Journal of Cleaner Production, Vol. 18, 2010, pp. 1519-1529.

[28] Bauer, C. Ökobilanz von Lithium-Ionen Batterien. Analyse der Herstellung von Energiespeichern für den Einsatz in Batteriefahrzeugen. Eine Studie im Auftrag der Volkswagen AG. Paul Scherrer Institut. Technology Assessment. Villigen.

[29] Ishihara, K., N. Kihira, N. Terada, T. Iwahori, and K. Nishimura. Life cycle analysis of large-size lithium-ion secondary batteries developed in the Japanese national project.In Proceedings from 5th Ecobalance conference, Tsukuba, 2002.

[30] Amarakoon, S., J. Smith, and B. Segal. Application of life-cycle assessment to nanoscale technology: Lithium-ion batteries for electric vehicles.In, 2013.

[31] Ellingsen, L. A. W., G. Majeau-Bettez, B. Singh, A. K. Srivastava, L. O. Valøen, and A. H. Strømman. Life Cycle Assessment of a Lithium-Ion Battery Vehicle Pack. Journal of Industrial Ecology, Vol. 18, No. 1, 2014, pp. 113-124. 
[32] Majeau-Bettez, G., T. R. Hawkins, and A. H. Strømman. Life cycle environmental assessment of lithium-ion and nickel metal hydride batteries for plug-in hybrid and battery electric vehicles. Environmental science \& technology, Vol. 45, 2011, pp. 4548-4554.

[33] Dunn, J. B., L. Gaines, J. Sullivan, and M. Q. Wang. Impact of recycling on cradle-to-gate energy consumption and greenhouse gas emissions of automotive lithium-ion batteries. Environmental science \& technology, Vol. 46, 2012, pp. 12704-12710.

[34] Scrosati, B., and J. Garche. Lithium batteries: Status, prospects and future. Journal of Power Sources, Vol. 195, No. 9, 2010, pp. 2419-2430.

[35] Anderman, M. The Tesla Battery Report: Battery Technology, Analysis of the Gigafactory, and the Automakers' Perspectives. In, Advanced Automotive Batteries, 2014.

[36] California Air Resources Board. § 1962.1 Zero-emission vehicle standards for 2009 through 2017 model year passenger cars, light-duty trucks, and medium-duty vehicles.In, ca.gov, Sacramento, CA, 2011.

[37] State of California. Title 13, California Code of Regulations, Sections 2035, 2037, and 2038, Emission Control System Warranty Requirements for 1990 and Subsequent Model Year Passenger Cars, Light-Duty Trucks, and Medium-Duty Vehicles and Engines. Sacramento, CA, 2014.

[38] Scrosati, B. Electrode and Electrolyte Materials for Polymer-Based Lithium Batteries. Journal of The Electrochemical Society, Vol. 136, No. 10, 1989, pp. 2774-2782.

[39] Amine, K., R. Kanno, and Y. Tzeng. Rechargeable lithium batteries and beyond: Progress, challenges, and future directions. MRS Bulletin, Vol. 39, No. 05, 2014, pp. 395-401.

[40] Delucchi, M. A., C. Yang, A. F. Burke, J. M. Ogden, K. Kurani, J. Kessler, and D. Sperling. An assessment of electric vehicles: technology, infrastructure requirements, greenhouse-gas emissions, petroleum use, material use, lifetime cost, consumer acceptance and policy initiatives. Philosophical Transactions of the Royal Society A: Mathematical, Physical and Engineering Sciences, Vol. 372, No. 2006, 2014.

[41] Committee on the Assessment of Technologies for Improving Fuel Economy of Light-Duty Vehicles. Cost, Effectiveness and Deployment of Fuel Economy Technologies for Light-Duty Vehicles.In, Division on Engineering and Physical Sciences, National Research Council, Washington, DC, 2015.

[42] Anderman, M. Assessing the Future of Hybrid and Electric Vehicles: The xEV Industry Insider Report.In, Advanced Automotive Batteries, 2014.

[43] Barré, A., B. Deguilhem, S. Grolleau, M. Gérard, F. Suard, and D. Riu. A review on lithium-ion battery ageing mechanisms and estimations for automotive applications. Journal of Power Sources, Vol. 241, 2013, pp. 680-689.

[44] Ploehn, H. J., P. Ramadass, and R. E. White. Solvent diffusion model for aging of lithium-ion battery cells. Journal of The Electrochemical Society, Vol. 151, No. 3, 2004, pp. A456-A462.

[45] Song, H., Z. Cao, X. Chen, H. Lu, M. Jia, Z. Zhang, Y. Lai, J. Li, and Y. Liu. Capacity fade of LiFePO4/graphite cell at elevated temperature. Journal of Solid State Electrochemistry, Vol. 17, No. 3, 2013, pp. 599-605.

[46] Eddahech, A., O. Briat, and J.-M. Vinassa. Performance comparison of four lithium-ion battery technologies under calendar aging. Energy, Vol. 84, 2015, pp. 542-550. 
[47] Wood, E., J. Neubauer, A. D. Brooker, J. Gonder, and K. A. Smith. Variability of Battery Wear in Light Duty Plug-in Electric Vehicles Subject to Ambient Temperature, Battery Size, and Consumer Usage: Preprint. National Renewable Energy Laboratory, 2012.

[48] Shirk, M., and J. Wishart. Effects of Electric Vehicle Fast Charging on Battery Life and Vehicle Performance.In, SAE Technical Paper, 2015.

[49] Gu, W., Z. Sun, X. Wei, and H. Dai. A capacity fading model of lithium-ion battery cycle life based on the kinetics of side reactions for electric vehicle applications. Electrochimica Acta, Vol. 133, 2014, pp. 107-116.

[50] Zheng, Y., Y.-B. He, K. Qian, B. Li, X. Wang, J. Li, S. W. Chiang, C. Miao, F. Kang, and J. Zhang. Deterioration of lithium iron phosphate/graphite power batteries under high-rate discharge cycling. Electrochimica Acta, Vol. 176, 2015, pp. 270-279.

[51] British Standards Institute. PSA2050: Specification for the assessment of the life cycle greenhouse gas emissions of goods and services.In, London, UK, 2011.

[52] Myhre, G., D. Shindell, F.-M. Bréon, W. Collins, J. Fuglestvedt, J. Huang, D. Koch, J.-F. Lamarque, D. Lee, B. Mendoza, T. Nakajima, A. Robock, G. Stephens, T. Takemura, and H. Zhang. Anthropogenic and Natural Radiative Forcing. In Contribution of Working Group I to the Fifth Assessment Report of the Intergovernmental Panel on Climate Change, Cambridge University Press, New York, NY, 2014. pp. 659-740.

[53] Finnveden, G., M. Z. Hauschild, T. Ekvall, J. Guinée, R. Heijungs, S. Hellweg, A. Koehler, D. Pennington, and S. Suh. Recent developments in life cycle assessment. Journal of Environmental Management, Vol. 91, No. 1, 2009, pp. 1-21.

[54] Lloyd, S. M., and R. Ries. Characterizing, Propagating, and Analyzing Uncertainty in Life-Cycle Assessment: A Survey of Quantitative Approaches. Journal of Industrial Ecology, Vol. 11, No. 1, 2007, pp. 161-179.

[55] Livezey, R. E., and W. Chen. Statistical field significance and its determination by Monte Carlo techniques. Monthly Weather Review, Vol. 111, No. 1, 1983, pp. 46-59.

[56] Hauck, M., Z. Steinmann, I. Laurenzi, R. Karuppiah, and M. Huijbregts. How to quantify uncertainty and variability in life cycle assessment: the case of greenhouse gas emissions of gas power generation in the US. Environmental Research Letters, Vol. 9, No. 7, 2014, p. 074005.

[57] Matheys, J., W. Van Autenboer, J.-M. Timmermans, J. Van Mierlo, P. Van den Bossche, and G. Maggetto. Influence of functional unit on the life cycle assessment of traction batteries. The International Journal of Life Cycle Assessment, Vol. 12, No. 3, 2007, pp. 191-196.

[58] Marano, V., S. Onori, Y. Guezennec, G. Rizzoni, and N. Madella. Lithium-ion batteries life estimation for plug-in hybrid electric vehicles.In Vehicle Power and Propulsion Conference, 2009. VPPC'09. IEEE, IEEE, 2009. pp. 536-543.

[59] Smith, K., M. Earleywine, E. Wood, J. Neubauer, and A. Pesaran. Comparison of plug-in hybrid electric vehicle battery life across geographies and drive cycles.In, SAE Technical Paper, 2012.

[60] Argonne National Laboratory. The Greenhouse Gases, Regulated Emissions, and Energy Use in Transportation (GREET) Model, 2014.In US Department of Energy, Argonne National Laboratory, Argonne National Lab and University of Chicago, Argonne, IL, 2014.

[61] Faria, R., P. Marques, P. Moura, F. Freire, J. Delgado, and A. T. de Almeida. Impact of the electricity mix and use profile in the life-cycle assessment of electric vehicles. Renewable and Sustainable Energy Reviews, Vol. 24, 2013, pp. 271-287. 
[62] Hadley, S. W., and A. A. Tsvetkova. Potential impacts of plug-in hybrid electric vehicles on regional power generation. The Electricity Journal, Vol. 22, No. 10, 2009, pp. 56-68.

[63] Hadley, S. W. Impact of plug-in hybrid vehicles on the electric grid.In, October, 2006.

[64] Jansen, K. H., T. M. Brown, and G. S. Samuelsen. Emissions impacts of plug-in hybrid electric vehicle deployment on the U.S. western grid. Journal of Power Sources, Vol. 195, No. 16, 2010, pp. 5409-5416.

[65] Weiller, C. Plug-in hybrid electric vehicle impacts on hourly electricity demand in the United States. Energy Policy, Vol. 39, No. 6, 2011, pp. 3766-3778.

[66] Kintner-Meyer, M., K. Schneider, and R. Pratt. Impacts assessment of plug-in hybrid vehicles on electric utilities and regional US power grids, Part 1: Technical analysis. Pacific Northwest National Laboratory, 2007.

[67] Carley, S. Decarbonization of the US electricity sector: Are state energy policy portfolios the solution? Energy Economics, Vol. 33, No. 5, 2011, pp. 1004-1023.

[68] ---. The era of state energy policy innovation: A review of policy instruments. Review of Policy Research, Vol. 28, No. 3, 2011, pp. 265-294.

[69] James Archsmith, A. K., James Rapson. From Cradle to Junkyard: Assessing the life cycle greenhouse gas benefits of electric vehicles. Journal of Transportation Economics, (Accepted).

[70] Henriksson, P. J., R. Heijungs, H. M. Dao, L. T. Phan, G. R. de Snoo, and J. B. Guinée. Product Carbon Footprints and Their Uncertainties in Comparative Decision Contexts. PloS one, Vol. 10, No. 3, 2015, p. e0121221.

[71] Kala, Z. Fuzzy sets theory in comparison with stochastic methods to analyse nonlinear behaviour of a steel member under compression. 2005.

[72] Armand, M., and J.-M. Tarascon. Building better batteries. Nature, Vol. 451, No. 7179, 2008, pp. 652-657.

[73] Kendall, A., and L. Price. Incorporating Time-Corrected Life Cycle Greenhouse Gas Emissions in Vehicle Regulations. Environmental Science \& Technology, Vol. 46, No. 5, 2012, pp. 2557-2563. 
Figure Captions

Figure 1. Comparing Lithium chemistries for automotive traction batteries

Figure 2. Composition of lithium batteries and material GHG emissions by chemistry: (a) mean composition of traction batteries by components (\% of total mass) (b) mean GHG emissions from materials by chemistry ( $\%$ of total battery production emissions)

Figure 3. Mean battery production emissions estimates for LIB chemistries

Figure 4. Battery production emissions by PEV vehicle type and all-electric range

Figure 5. Production and fuel cycle emissions rates

Figure 6. Sensitivity to key parameters

Figure 7. GHG emissions comparison for to other studies for PEV LIB Battery Production and PEV Operation 


\begin{tabular}{|c|c|c|c|}
\hline \multirow{3}{*}{$\begin{array}{l}\text { Automotive Lithium Chemistries } \\
\text { Nickelate - NCA/NCM } \\
\text { Manganese Spinel - LMO } \\
\text { Phosphate - LFP } \\
\text { Titanate - LTO }\end{array}$} & $\begin{array}{l}\text { Higher material costs, high } \\
\text { performance potential }\end{array}$ & & \multirow{2}{*}{$\begin{array}{l}\text { Higher } \\
\text { Energy } \\
\text { Density }\end{array}$} \\
\hline & $\begin{array}{l}\text { Low cost, low cycle life } \\
\text { expectations }\end{array}$ & \multirow{2}{*}{$\begin{array}{l}\text { Better Charge } \\
\text { \& Thermal } \\
\text { Stability }\end{array}$} & \\
\hline & $\begin{array}{l}\text { Low material costs and long } \\
\text { cycle life, but lower cell } \\
\text { potentials can lead to larger } \\
\text { systems and higher pack } \\
\text { costs }\end{array}$ & & $\begin{array}{l}\text { Density } \\
\text { Higher } \\
\text { Operating } \\
\text { Voltage }\end{array}$ \\
\hline
\end{tabular}

Figure 1 

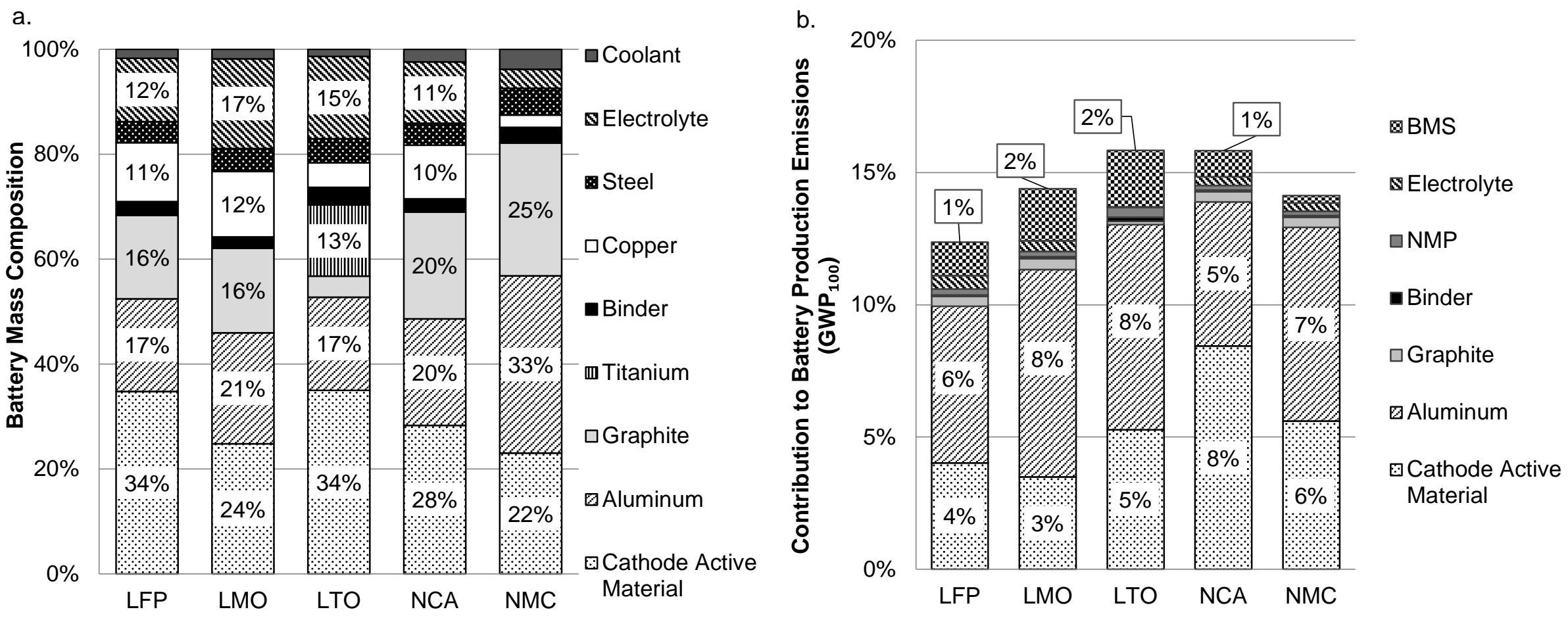

Figure 2 

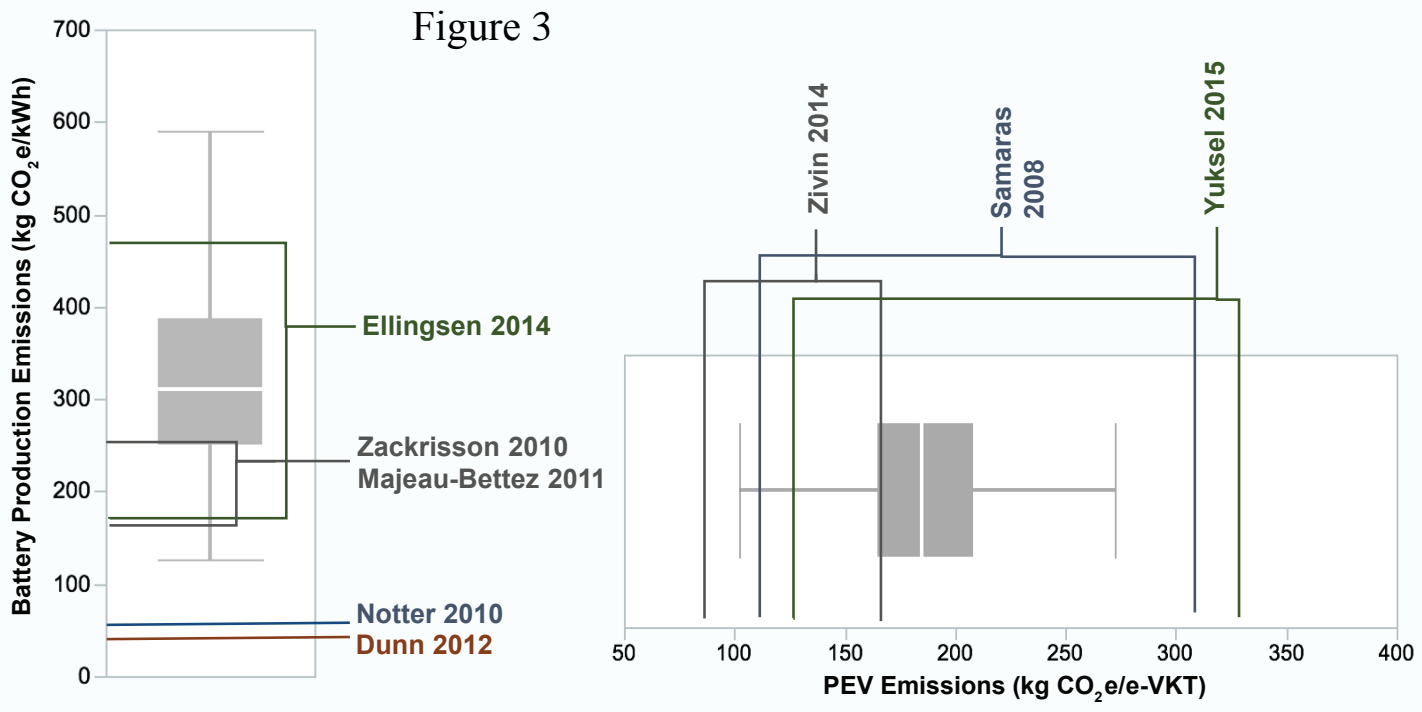


\section{Figure 4}

$\mathrm{g} \mathrm{CO}_{2} \mathrm{e} / \mathrm{e}-\mathrm{VKT}$
75
100
125
150
175

Operating Grid Intensity

Climate Load

Charge Efficiency

Battery Cycles

Climate Capacity Loss

Material Emissions

Calendar/Cycle Loss

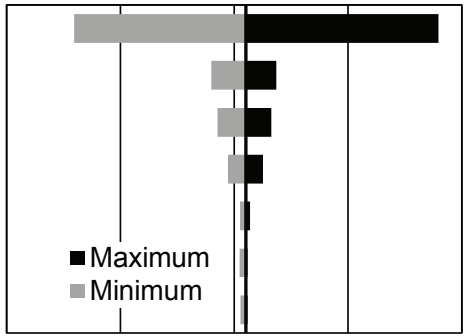


Figure 5

Battery

Production

Emissions

Fuel Cycle

Emissions

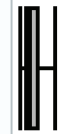

0

50

100

150

200

250

300

350

400

Battery Production Emissions (kg CO $2 \mathrm{e} / \mathrm{kWh}$ ) 
Figure 7

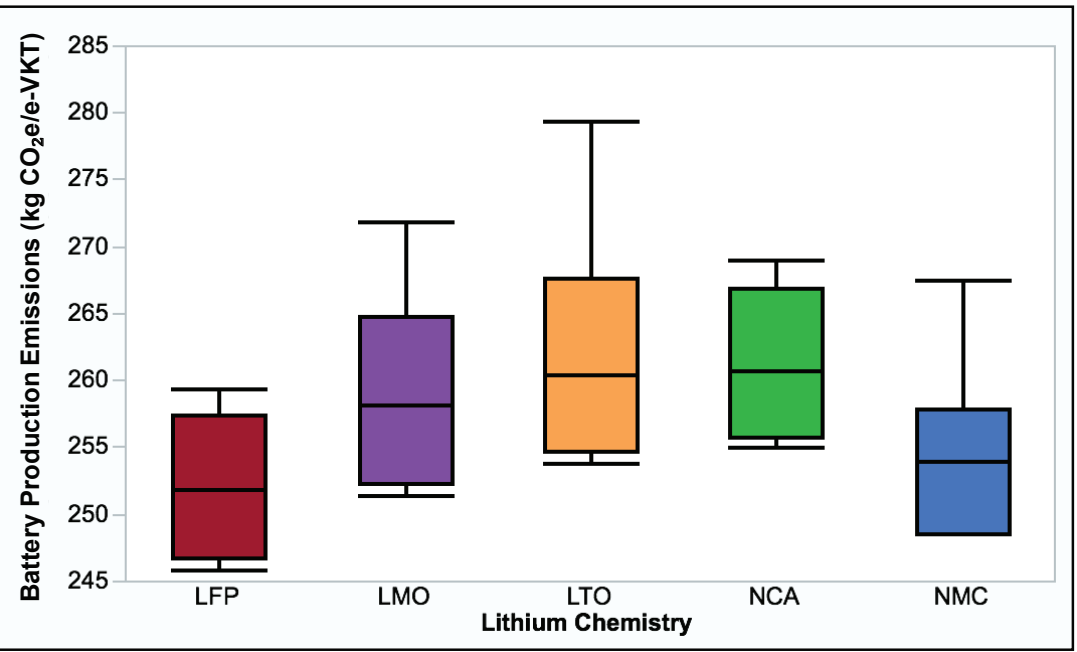


Table 3. Summary of parameter distributions

\begin{tabular}{|c|c|c|c|c|}
\hline Parameter & Minimum & Likeliest & Maximum & Distribution \\
\hline \multicolumn{5}{|c|}{ Production Emissions } \\
\hline Cell Production Energy (MJ/kWh) & 316 & 960 & 2318 & fuzzy \\
\hline Pack Assembly Energy (MJ/kWh) & \multicolumn{3}{|c|}{$\sim \mathrm{N}(0.014,0.01)$} & normal \\
\hline Grid Emissions Factor (kg/kWh) & \multicolumn{3}{|c|}{$\sim \log \mathrm{N}(\mu=0.81, \sigma=0.13, \mathrm{k}=-0.14)$} & Log-normal \\
\hline \multicolumn{5}{|l|}{ Battery Cycle Life by Chemistry } \\
\hline NCA Battery Cycles & 400 & 1000 & 3000 & fuzzy \\
\hline NMC Battery Cycles & 1000 & 1700 & 3000 & fuzzy \\
\hline LMO Battery Cycles & 305 & 685 & 1000 & fuzzy \\
\hline LFP Battery Cycles & 1600 & 3200 & 5039 & fuzzy \\
\hline LTO Battery Cycles & 2000 & 5000 & 6800 & fuzzy \\
\hline \multicolumn{5}{|c|}{ Material Production Emissions $\left(\mathrm{kg} \mathrm{CO}_{2} \mathrm{e} / \mathrm{kWh}\right)$ by Battery Type } \\
\hline NCA BEV & 39.86 & 42.87 & 45.54 & fuzzy \\
\hline NCA PHEV & 44.94 & 53.3 & 61.14 & fuzzy \\
\hline NMC BEV & 33.36 & 34.78 & 36.22 & fuzzy \\
\hline NMC PHEV & 38.78 & 48.32 & 53.85 & fuzzy \\
\hline LMO BEV & 36.29 & 39.83 & 42.98 & fuzzy \\
\hline LMO PHEV & 43.07 & 522.84 & 58.65 & fuzzy \\
\hline LFP BEV & 30.77 & 33.9 & 36.68 & fuzzy \\
\hline LFP PHEV & 35.89 & 43.21 & 49.56 & fuzzy \\
\hline LTO BEV & 28.17 & 31.79 & 34.98 & fuzzy \\
\hline LTO PHEV & 35.15 & 46.85 & 53.26 & fuzzy \\
\hline \multicolumn{5}{|c|}{ Battery Charge and Discharge and Battery Aging } \\
\hline Charger Efficiency & $85 \%$ & -- & $95 \%$ & uniform \\
\hline Climate Induced Degradation & $0 \%$ & -- & $20 \%$ & uniform \\
\hline Climate Accessory Load & $0 \%$ & & $15 \%$ & uniform \\
\hline
\end{tabular}


Table 2. Traction battery design scenarios and simulated PEVs (energy requirement is calculated, all other data are from the US Department of Energy's Advanced Fuels Data Center (23))

\begin{tabular}{|c|c|c|c|c|c|}
\hline $\begin{array}{c}\text { Battery } \\
\text { Scenario }\end{array}$ & $\begin{array}{l}\text { PEV } \\
\text { Type }\end{array}$ & Vehicle Model & $\begin{array}{c}\text { Battery } \\
\text { Size (kWh) }\end{array}$ & $\begin{array}{c}\text { Motor } \\
\text { Power } \\
(k W)\end{array}$ & $\begin{array}{c}\text { Energy } \\
\text { Requirement } \\
\text { (Wh/VKT) }\end{array}$ \\
\hline \multirow{6}{*}{$\begin{array}{c}\text { Short-range } \\
\text { PHEV }\end{array}$} & \multirow{6}{*}{$\begin{array}{c}\text { PHEV } \\
15\end{array}$} & Toyota Prius Plug-in Hybrid & 4.5 & 18.0 & 251.4 \\
\hline & & Honda Accord Plug-in Hybrid & 6.7 & 124.0 & 318.1 \\
\hline & & BMW I8 & 7.1 & 125.0 & 294.1 \\
\hline & & McLaren Automotive Limited P1 & 4.7 & 132.0 & 154.0 \\
\hline & & Ford Fusion Energi Plug-in Hybrid & 7.6 & 68.0 & 234.4 \\
\hline & & Ford C-Max Energi Plug-In Hybrid & 7.6 & 68.0 & 234.4 \\
\hline \multirow{2}{*}{$\begin{array}{l}\text { Mid-range } \\
\text { PHEV }\end{array}$} & \multirow{2}{*}{$\begin{array}{c}\text { PHEV } \\
40\end{array}$} & Chevrolet ELR & 16.9 & 126.0 & 283.5 \\
\hline & & Cadillac Volt & 15.7 & 111.0 & 256.1 \\
\hline $\begin{array}{c}\text { Long-range } \\
\text { PHEV }\end{array}$ & $\begin{array}{c}\text { PHEV } \\
80 \\
\end{array}$ & BMW i3 (REX) & 21.6 & 96.0 & 175.5 \\
\hline \multirow{3}{*}{$\begin{array}{c}\text { Short-range } \\
\text { BEV }\end{array}$} & \multirow{3}{*}{ EV 40} & Scion iQ EV & 12.0 & 110.0 & 195.5 \\
\hline & & Mitsubishi Motors Corporation i-MiEV & 17.0 & 49.0 & 165.3 \\
\hline & & Mercedes-Benz Smart fortwo EV & 17.6 & 55.0 & 161.1 \\
\hline \multirow{5}{*}{$\begin{array}{l}\text { Mid-range } \\
\text { BEV (Low } \\
\text { Power) }\end{array}$} & \multirow{5}{*}{ EV 80} & Nissan Leaf & 23.8 & 80.0 & 175.8 \\
\hline & & Kia Soul Electric & 27.0 & 81.0 & 180.4 \\
\hline & & FIAT 500e & 24.0 & 82.0 & 171.7 \\
\hline & & Volkswagen e-Golf & 27.1 & 85.0 & 202.7 \\
\hline & & Honda FIT & 20.0 & 92.0 & 50.0 \\
\hline \multirow{3}{*}{$\begin{array}{l}\text { Mid-range } \\
\text { BEV (High } \\
\text { Power) }\end{array}$} & \multirow{3}{*}{ EV 80} & Chevrolet SPARK EV & 22.2 & 104.0 & 168.2 \\
\hline & & Ford Focus Electric FWD & 26.3 & 107.0 & 214.6 \\
\hline & & Mercedes-Benz B-Class Electric & 44.0 & 132.0 & 314.5 \\
\hline Long-range & $\mathrm{EV}$ & Toyota RAV4 EV & 50.2 & 126.0 & 302.7 \\
\hline $\mathrm{BEV}$ & 100 & Tesla Motors Model S & 86.0 & 164 and 350 & 222.6 \\
\hline
\end{tabular}


Table 1. Lithium chemistries for PEV traction batteries $(17 ; 19 ; 20)$

\begin{tabular}{|c|c|c|c|c|c|}
\hline Chemistry & $\begin{array}{c}\text { Lithium } \\
\text { Nickel } \\
\text { Cobalt } \\
\text { Aluminum } \\
\text { Oxide }\end{array}$ & $\begin{array}{c}\text { Lithium } \\
\text { Nickel } \\
\text { Manganese } \\
\text { Cobalt } \\
\text { Oxide }\end{array}$ & $\begin{array}{c}\text { Lithium } \\
\text { Manganese } \\
\text { Oxide }\end{array}$ & $\begin{array}{c}\text { Lithium } \\
\text { Iron } \\
\text { Phosphate }\end{array}$ & $\begin{array}{c}\text { Mithium } \\
\text { Manganese } \\
\text { with } \\
\text { Titanate } \\
\text { Oxide } \\
\text { Anode }\end{array}$ \\
\hline Chemistry group & \multicolumn{2}{|c|}{ Nickelate } & $\begin{array}{c}\text { Manganese } \\
\text { Spinel }\end{array}$ & Phosphate & Titanate \\
\hline Abbreviation & NCA & NMC & LMO & LFP & LMO/LTO \\
\hline $\begin{array}{c}\text { Voltage } \\
\text { (Nominal/Max) }\end{array}$ & $3.6 / 4.2$ & $3.6 / 4.2$ & $3.6 / 4.0$ & $3.2 / 3.6$ & $2.4 / 2.8$ \\
\hline $\begin{array}{c}\text { Energy Density } \\
\text { (Wh/kg) }\end{array}$ & $100-150$ & $75-170$ & $100-120$ & $80-115$ & $45-100$ \\
\hline $\begin{array}{c}\text { Estimated Automotive } \\
\text { Cycles }\end{array}$ & $2000-3000$ & $1000-2000$ & $300-700$ & $2000-3000$ & $>5000$ \\
\hline
\end{tabular}

